\title{
The effect of spike time dependent plasticity on activity patterns in the basal ganglia
}

\author{
Marcel AJ Lourens ${ }^{1 *}$, Jasmine A Nirody², Hil GE Meijer ${ }^{1}$, Tjitske Heida ${ }^{3}$, Stephan A van Gils ${ }^{1}$ \\ From Twentieth Annual Computational Neuroscience Meeting: CNS*2011 \\ Stockholm, Sweden. 23-28 July 2011
}

\begin{abstract}
Background
Pathophysiology of Parkinson's disease (PD) is characterized by increased firing rates of cells in the basal ganglia, a tendency toward bursting and abnormal synchronization in cells of subthalamic nucleus (STN) and globus pallidus pars externa (GPe) [1]. In advanced PD, deep brain stimulation (DBS) can be used to disrupt this pathological activity. The standard protocol for DBS is continuous high frequency stimulation of target cells, such as STN. It has been proposed that short-duration stimulation protocols may also disrupt the pathological activity [2]. The mechanism underlying this protocol is supposedly synaptic plasticity. The goal of this study is to investigate, with a biophysically plausible model, the role of synaptic plasticity in stabilizing firing patterns in the basal ganglia.
\end{abstract}

\section{Method}

We use a STN-GPe network model consisting of 8-20 STN and GPe cells connected to each other via a sparse structured architecture [3]. The dynamics of each cell is described by a single-compartment conductance-based model. We change the weights of the excitatory projections from STN to GPe with a pre-post spike-timing dependent plasticity (STDP) rule. We apply DBS as a train of positive current pulses injected directly into each STN cell.

\section{Results}

Depending on both cell and synaptic parameters, the network model without STDP displays a variety of activity patterns, including synchronous, correlated dynamics and irregular firing. In the model with STDP, the nearly

\footnotetext{
* Correspondence: M.A.J.Lourens@utwente.nl

'Department of Applied Mathematics, University of Twente, Enschede, 7500 $A E$, The Netherlands

Full list of author information is available at the end of the article
}

clustered activity patterns disappears and we observe only irregular firing or synchronized activity. Application of DBS replaces the clustered activity by high frequency firing. Switching DBS off, the network without STDP returns to a pathological activity pattern. In contrast, with STDP the temporary application of DBS changes the connectivity such that the network does not fall back to the clustered activity.

\section{Discussion}

Synaptic plasticity is the nervous system's way to learn and adapt to sensory inputs, and this adaptation can strengthen both desired and pathological states. STDP pushes network dynamics to irregular (health) or synchronized (pathological) state, depending on parameter values. Moreover, our results suggest that DBS can use STDP to teach the network to fire in a less pathological manner. This teaching ability of DBS can be exploited to develop more efficient stimulation protocols.

\section{Acknowledgements}

The authors gratefully acknowledge the support of the BrainGain Smart Mix Programme of the Netherlands Ministry of Economic Affairs and the Netherlands Ministry of Education, Culture and Science.

\section{Author details}

${ }^{1}$ Department of Applied Mathematics, University of Twente, Enschede, 7500 AE, The Netherlands. ${ }^{2}$ New York Medical College, Valhalla, NY 10595, USA. ${ }^{3}$ Department of Electrical Engineering, University of Twente, Enschede, 7500 $A E$, The Netherlands.

Published: 18 July 2011

\section{References}

1. Brown P: Oscillatory nature of human basal ganglia activity: Relationship to the pathophysiology of Parkinson's disease. Movement Disorder 2003, 18(4):357-363.

2. Hauptmann C, Tass PA: Cumulative and after-effects of short and weak coordinated reset stimulation: a modeling study. Journal of Neural Engineering 2009, 6:016004

\section{() Biomed Central}

(c) 2011 Lourens et al; licensee BioMed Central Ltd. This is an open access article distributed under the terms of the Creative Commons Attribution License (http://creativecommons.org/licenses/by/2.0), which permits unrestricted use, distribution, and reproduction in any medium, provided the original work is properly cited. 
3. Terman D, Rubin JE, Yew AC, Wilson CJ: Activity patterns in a model for the subthalamopallidal network of the basal ganglia. The Journal of Neuroscience 2002, 22(7):2963-2976.

4. Morrison A, Diesmann M, Gerstner W: Phenomenological models of synaptic plasticity based on spike timing. Biological Cybernetics 2008 98(6):459-478

doi:10.1186/1471-2202-12-S1-P351

Cite this article as: Lourens et al.: The effect of spike time dependent plasticity on activity patterns in the basal ganglia. BMC Neuroscience 2011 12(Suppl 1):P351.

Submit your next manuscript to BioMed Central and take full advantage of:

- Convenient online submission

- Thorough peer review

- No space constraints or color figure charges

- Immediate publication on acceptance

- Inclusion in PubMed, CAS, Scopus and Google Scholar

- Research which is freely available for redistribution

Submit your manuscript at www.biomedcentral.com/submit
C Biomed Central 